\title{
Whole-body amino acid composition of adult fancy ranchu goldfish (Carassius auratus)
}

\author{
Donna L. Snellgrove* and Lucille G. Alexander \\ Waltham Centre for Pet Nutrition, Freeby Lane, Waltham-on-the-Wolds, Melton Mowbray, Leicestershire LE14 4RT, UK
}

(Received 22 October 2010 - Revised 21 April 2011 - Accepted 3 May 2011)

\begin{abstract}
Aqua feeds should be formulated to provide complete and balanced nutrition to achieve optimal health and growth in fish, including adequate levels of essential amino acids (EAA). There are few or no data relating to the EAA requirements for ornamental fish species, with the majority of quantitative data for these nutrients being available for commercially farmed fish. The determination of EAA requirements is usually established through dose-response studies, which can be costly and time consuming, especially if determining the requirement for many amino acids (AA). An alternative method for predicting the EAA of fish, which is also relatively fast and inexpensive, is the assessment of whole-body AA composition. A total of eight goldfish with a mean wet weight of $34 \cdot 2$ (SEM 1.4) g were obtained as a result of a routine cull by breeders. The fish were freeze-dried and AA was content analysed by hydrolysis or performic 'acid' oxidation. EAA values ranged between 0.97 (SEM 0.02) for tryptophan and 7.9 (SEM 0.14) for lysine (g/100 g AA). Compositional data were also used to estimate the essential amino acid ratios of these fish. The findings are in agreement with those for juvenile common goldfish, suggesting that there are no differences in whole-body AA composition between juvenile and adult, or fancy and common goldfish. However, these indices do not provide a quantitative total amount of each AA required by the fish, but can be used proportionally to provide guidelines to formulate diets for ornamental species.
\end{abstract}

Key words: Goldfish: Amino acid: Carassius auratus: Ornamental fish

The largest and potentially most expensive component of a feed formulation for fish is protein, which needs to provide sufficient levels of the ten essential amino acids (EAA) to meet their requirements. The requirement for arginine, histidine, isoleucine, leucine, lysine, methionine, phenylalanine, threonine, tryptophan and valine has been demonstrated in all fish species examined to date ${ }^{(1)}$. In effect, the EAA dietary profile should reflect the requirement profile. The most common method for quantifying dietary EAA requirements is the production of a dose-response curve using experimental diets with graded inclusion levels of the amino acids (AA) in question, and measuring weight gain as the response ${ }^{(2)}$. This method has been used to quantitatively establish EAA for a selection of commercially cultured fish, including tilapia, salmon, milkfish, common carp and channel catfish ${ }^{(1)}$. However, this method is both time consuming and costly, and can cause discrepancies as fish fed diets utilising casein as the protein source supplemented with free AA have shown lower growth rates when compared with fish fed diets with similar EAA profiles, based on a fishmeal protein source. In the last couple of decades, the measurement of whole-body
EAA has been used to estimate dietary EAA requirements ${ }^{(3)}$. This method, being an inexpensive fast alternative to doseresponse studies, has been recommended for fish species whose EAA requirements have not yet been determined ${ }^{(4)}$. Consequently, EAA data have now been quantified for fish species such as European seabass, gilthead seabream, turbot, Atlantic halibut, flounder, sturgeon, Arctic charr and yellow perch $^{(5-9)}$. Still, data for ornamental fish are limited and restricted to a few species, namely discus and black-finned $\operatorname{pacu}^{(10,11)}$.

Fancy goldfish have been selectively bred for centuries to enhance such traits as finnage, eye shape and position, body colouration, scalation and body shape. Although all derived from the same species (Carassius auratus), there is presently a vast range of expressed phenotypes. Standard fusiformshaped goldfish are used as baitfish in the USA, and the whole-body AA composition of juvenile $(2 \cdot 2-5 \cdot 0 \mathrm{~g})$ goldfish has been established ${ }^{(12)}$. The aim of the present study was to determine the whole-body AA composition of adult fancy ranchu goldfish for comparative assessment with closely related species.

Abbreviations: AA, amino acid; A:E ratio, essential amino acid ratio; EAA, essential amino acid.

*Corresponding author: Dr D. L. Snellgrove, fax +1 664 415440, email donna.snellgrove@effem.com 
Table 1. Amino acid (AA) composition of whole-body tissue of adult fancy ranchu goldfish ( $n$ 8)

\begin{tabular}{lcc}
\hline AA & AA $(g / 100 \mathrm{~g})$ & SEM \\
\hline Ala & 7.22 & 0.14 \\
Arg & 6.57 & 0.10 \\
Asp & 9.58 & 0.16 \\
Cys & 0.94 & 0.04 \\
Glu & 13.88 & 0.30 \\
Gly & 9.02 & 0.16 \\
His & 2.53 & 0.04 \\
Ile & 4.06 & 0.10 \\
Leu & 7.52 & 0.18 \\
Lys & 7.90 & 0.14 \\
Met & 2.80 & 0.06 \\
Phe & 4.34 & 0.08 \\
Pro & 5.62 & 0.12 \\
Ser & 4.72 & 0.14 \\
Thr & 4.51 & 0.10 \\
Trp & 0.97 & 0.02 \\
Tyr & 3.24 & 0.08 \\
Val & 4.55 & 0.08 \\
\hline
\end{tabular}

\section{Materials and methods}

The study was reviewed and approved by the WALTHAM ${ }^{\circledR}$ (Leicestershire, UK) Ethics Review Committee. A total of eight adult, male fancy ranchu goldfish, aged 6 months, with a mean weight of 34.3 (SEM 1.4) g obtained as a result of routine culls by breeders, were used to assess whole-body AA composition. Individual fish were used for AA analysis ( $n$ 8). The fish were freeze-dried whole with the gastrointestinal tract intact using an Edwards moduylo freeze drier (Edwards High Vacuum International, West Sussex, UK) and ground using a small coffee grinder before AA analysis. Alanine, arginine, aspartic acid, glutamic acid, glycine, histidine, isoleucine, leucine, lysine, phenylalanine, proline, serine, threonine, tyrosine and valine were analysed by acid hydrolysis followed by ion exchange chromatography using ninhydrin derivatisation. Cysteine and methionine were analysed by performic oxidation followed by ion exchange chromatography using ninhydrin derivatisation, and tryptophan by alkaline hydrolysis followed by HPLC (AOAC methods) ${ }^{(13)}$. From the whole-body AA composition, essential amino acid ratios (A:E ratio) were calculated as follows
$\mathrm{A}: \mathrm{E}$ ratio $=($ essential $\mathrm{AA}$ content $/$ total essential AA content including cysteine and tyrosine) $\times 1000$.

\section{Results}

The whole-body AA composition of adult fancy ranchu goldfish is presented in Table 1 . The A:E ratio for adult fancy ranchu goldfish derived from whole-body AA composition are presented in Table 2, alongside previously published data for standard goldfish and carp. Generally, data appear to be similar between fish with only a couple of exceptions: the leucine A:E ratio for carp, which was considerably lower at 101, compared with 147 for goldfish and 151 for fancy goldfish. Additionally, there was also a discrepancy for both the phenylalanine and methionine A:E ratio, which were lower in fancy goldfish than the other two fish varieties.

\section{Discussion}

The whole-body AA values determined in the present study for adult fancy ranchu goldfish can be utilised to provide guidelines for formulating diets for this ornamental species, and are similar to those published for other fish species ${ }^{(10,11,12,14)}$. This relationship between whole-body EAA and dietary requirement has been directly substantiated in several fish species, although it should be noted that these indices do not provide a quantitative total amount of each AA required by the fish. It should be considered that these fish did not have their gastrointestinal tracts removed before AA analysis; therefore, the absolute values for the whole-body profile may be slightly higher. However, these fish were relatively small and would have been fed as a group on the same diet before culling, so that any over-estimation will have been relative between the fish. The relationship between whole-body A:E ratio of adult fancy ranchu goldfish when compared with those for both carp and juvenile standard goldfish demonstrates only slight differences between these cyprinid fish, for methionine and phenylalanine. Underestimations for leucine have been observed when calculating dietary requirements of this AA against whole-body values for adult

Table 2. Essential amino acid (EAA) requirement values for juvenile common carp, and associated essential amino acid $(A A)$ ratios (A:E ratio) of juvenile common carp, juvenile goldfish and adult fancy ranchu goldfish $(n 8)$

\begin{tabular}{|c|c|c|c|c|c|c|}
\hline $\mathrm{AA}$ & $\begin{array}{l}\text { Carp } \\
\text { requirement }^{*}\end{array}$ & $\begin{array}{c}\text { Carp whole } \\
\text { body } A: E \text { ratios } \dagger\end{array}$ & $\begin{array}{l}\text { Goldfish whole } \\
\text { body A:E ratios } \ddagger\end{array}$ & SEM & $\begin{array}{l}\text { Fancy goldfish whole } \\
\text { body A:E ratios }\end{array}$ & SEM \\
\hline Arg & $4 \cdot 3$ & 131 & 134 & 3 & 132 & 2 \\
\hline His & $2 \cdot 1$ & 64 & 51 & 3 & 51 & 1 \\
\hline Ile & 2.5 & 76 & 78 & 2 & 81 & 2 \\
\hline Leu & $3 \cdot 3$ & 101 & 147 & 1 & 151 & 3 \\
\hline Lys & 5.7 & 174 & 169 & 2 & 158 & 3 \\
\hline Met & $3 \cdot 1$ & 95 & 81 & 2 & 56 & 1 \\
\hline Phe & 6.5 & 104 & 142 & 5 & 87 & 2 \\
\hline Thr & 3.9 & 119 & 92 & 1 & 90 & 2 \\
\hline Trp & 0.8 & 24 & 19 & 1 & 19 & 0.4 \\
\hline Val & 3.6 & 110 & 88 & 1 & 91 & 2 \\
\hline
\end{tabular}

* Values from National Research Council, 1993.

$\dagger($ EAA/total EAA including cysteine and tyrosine $) \times 1000$

\pm Values from Gatlin III, 1987 
carp $^{(12)}$. Additionally, the arginine requirement of hybrid striped bass has been underestimated using whole-body EAA concentrations ${ }^{(15)}$, suggesting that is not uncommon for slight inconsistencies to exist between AA and fish species. Various proposals have been made as to the variation in AA requirements between species, including the relative proportions of muscle tissue, particularly during a growth phase, and the physiological status of the fish, availability of $\mathrm{AA}$ and endogenous turnover of $\mathrm{EAA}^{(16,17)}$. Although the A:E ratio of EAA do not display variability when compared with the A:E ratio of the EAA requirements, implying that wholebody EAA determination may be more accurate than EEA determination through dietary methods ${ }^{(4)}$. The present study also demonstrates that when compared with other published data, age or size of fish does not influence the whole-body AA content or A:E ratio. This suggests that the dietary requirement for EAA's remains constant regardless of life stage, unlike protein level, which will vary. Such findings have also been established in other fish species such as the silver perch, channel catfish and common carp ${ }^{(16,18,19)}$.

The fundamental nutrient requirements between standard goldfish and the many fancy goldfish varieties could be expected to be similar, as they have been selectively bred from the same species. Using data from this study in addition to others published for cyprinid fish, the production of the diets formulated to contain the protein with an optimal AA profile, would benefit the ornamental fish species. Particularly, as feeding excess levels of EAA can result in increased ammonia excretion and poor water quality ${ }^{(20)}$, which is of high importance in a closed aquarium system.

\section{Acknowledgements}

There were no conflicts of interest to disclose. The present study received no specific grant from any funding agency in the public, commercial or not-for-profit sectors. Principal investigator, data collection and manuscript prepared by D. L. S. and intellectual input and support from L. G. A.

\section{References}

1. NRC (National Research Council) (1993) Nutrient Requirements of Fish, pp. 114. Washington, DC: National Academy Press.

2. Wilson RP (2002) Amino acids and protein. In Fish Nutrition, 3rd ed., pp. 144-181 [JE Halver and RW Hardy, editors]. New York, NY: Academic Press, Inc.

3. Ogino C (1980) Requirements of carp and rainbow trout for essential amino acids. Bull Jap Soc Sci Fish 46, 171-174.

4. Akiyama T, Oohara I \& Yamamoto T (1997) Comparison of essential amino acid requirements with $\mathrm{A} / \mathrm{E}$ ratio among fish species (review paper). Fish Sci 63, 963-970.
5. Kaushik SJ (1998) Whole body amino acid composition of European seabass (Dicentrarchus labrax), gilthead seabream (Sparus aurata) and turbot (Psetta maxima) with an estimation of their IAA requirement profiles. Aquat Living Resour 11, 355-358.

6. Kim JD \& Lall SP (2000) Amino acid composition of whole body tissue of Atlantic halibut (Hippoglossus bippoglossus), yellowtail flounder (Pleuronectes ferruginea) and Japanese flounder (Paralichthys olivaceus). Aquaculture $\mathbf{1 8 7}$, $367-373$.

7. Ng WK \& Hung SSO (1994) Amino acid composition of whole body, egg and selected tissues of white sturgeon (Acipenser transmontanus). Aquaculture 126, 329-339.

8. Gurure R, Atkinson J \& Moccia R (2007) Amino acid composition of Artic charr, Salvelinus alpinus (L.) and the prediction of dietary requirements for essential amino acids. Aquacult Nutr 13, 266-272.

9. Hart SD, Brown BJ, Gould NL, et al. (2010) Predicting the optimal dietary essential amino acid profile for growth of juvenile yellow perch with whole body amino acid concentration. Aquacult Nutr 16, 248-253.

10. Chong ASC (2004) Amino acid profile of various body tissues and eggs of discus fish, Symphysodon aequifasciata. J Appl Aqua 16, 157-168.

11. Van der Meer MB \& Verdegem MCJ (1996) Comparison of amino acid profiles of feeds and fish as a quick method for selection of feed ingredients: a case study for Colossoma macropomum (Cuvier). Aquacult Res 27, 487-495.

12. Gatlin III DM (1987) Whole-body amino acid composition and comparative aspects of amino acid nutrition of the goldfish, golden shiner and fathead minnow. Aquaculture 60, 223-229.

13. AOAC (2003) Official Methods of Analysis, 16th ed. Arlington, VA: Association of Official Analytical Chemists, Inc.

14. Mohanty SN \& Kaushik SJ (1991) Whole body amino acid composition of Indian major carps and its significance. Aquat Living Resour 4, 61-64.

15. Twibell RG, Griffen ME, Martin B, et al. (2003) Predicting dietary essential amino acid requirements for hybrid striped bass. Aquacult Nutr 9, 373-381.

16. Wilson RP \& Poe WE (1985) Relationship of whole body and egg essential amino acid patterns to amino acid requirement patterns in channel catfish, Ictalurus punctatus. Comp Biochem Physiol 80B, 385-388.

17. Baker PB, Dabrowski K \& Garling DL (1996) Nutrition and feeding of yellow perch Perca flavescens. J Appl Ichthyol 12, $171-174$.

18. Ngamsnae P, De Silva SS \& Gunasekera RM (1999) Arginine and phyenylalanine requirement of juvenile silver perch Bidyanus bidyanus and validation of the use of body amino acid composition for estimating individual amino acid requirements. Aquacult Nutr 5, 173-180.

19. Schwarz FJ \& Kirchgessner M (1988) Amino acid composition of carp (Cyprinus carpio L.) with varying protein and energy supplies. Aquaculture 72, 307-317.

20. Cai T, Wermerskirchen J \& Adelman IR (1996) Ammonia excretion rate indicates dietary protein adequacy for fish. Prog Fish-Cult 58, 124-127. 